\title{
THE IMPLEMENTATION OF RESEARCH BASED LEARNING MATERIALS ON STUDENT LEARNING COMPETENCY IN ISLAMIC HIGHER INSTITUTION
}

\section{Tenny Sudjatnika}

UIN Sunan Gunung Djati Bandung

Jl. A. H. Nasution 105 Bandung, Indonesia, 40614

Email:tennysudjatnika@uinsgd.ac.id

Received: 06, 2020. Accepted: 06, 2021. Published: 06, 2021

\begin{abstract}
The study on research-based learning material needs to be introduced in universities in order to achieve student competence. The purpose of this study is to investigate the contribution of teaching materials for Islamic Studies courses to be internalized in order to achieve the competence of English literature study program. This research applied qualitative method using an action research approach. Data were collected using tests, observations and interviews. The data were analyzed in the form of student learning performance. Their performance included students' thinking styles, patterns of processing information, attitudes and their work. Based on Thorndike's theory of connectionism, it was found that the draft teaching materials implemented through the classroom learning process in the form of thinking styles and ways of processing information were in accordance with their competencies. The implementation of the learning process was carried out through the internalization of Islamic educational values which can be seen in the attitude of students' politeness and the work they obtained.
\end{abstract}

Keywords: Connectionism Theory, Learning Model, Teaching Materials

\begin{abstract}
ABSTRAK
Kajian materi pembelajaran berbasis penelitian diperkenalkan di perguruan tinggi untuk mencapai kompetensi mahasiswa. Penelitian ini bertujuan mengetabui kontribusi bahan ajar mata kuliah Studi Islam untuk diinternalisasikan dalam pencapaian kompetensi program studi sastra Inggris. Penelitian ini menggunakan metode kualitatif dengan pendekatan penelitian tindakan. Pengumpulan data dilakukan dengan menggunakan tes, observasi dan wawancara. Prestasi belajar mahasiswa dijadikan sebagai data analisis meliputi gaya berpikir, pola pengolahan informasi, sikap dan pekerjaan mereka. Berdasarkan teori koneksionisme Thorndike ditemukan bahwa rancangan bahan ajar yang dilaksanakan melalui proses pembelajaran di kelas meliputi gaya berpikir dan cara pengolahan informasi sudah sesuai dengan kompetensi mahasiswa. Pelaksanaan proses pembelajaran dilakukan melahi internalisasi nilai-nilai pendidikan Islam dalam bentuk sikap kesopanan mabasiswa dan hasil karya yang diperoleh.
\end{abstract}

Kata Kunci: Teori Koneksionisme, Model Pembelajaran, Bahan Ajar

\section{INTRODUCTION}

The industrial era that is all technological and global has put human values aside. Mardia argues that religious education in higher education should be a companion for students in creating moral scholars in other words spiritual professionals, but the reality is that religious education is considered less successful in creating attitudes, behavior and morals of students. Education in higher education is faced with various challenges both internally and externally (Mardia, 2014). The current educational building needs to be built on a type of learning that is fundamental for life with a pattern of learning to know, learning to do, learning to live together, and learning to be someone (Ouharzoune, 2015). Learning to know is learning to master the instruments of knowledge, at least understanding the environment in developing 
work skills. In this case, communication skills become important for students in gaining knowledge about learning methods. The skills require learner to learn how to know. Lifelong learning is a representation of learning life skills; combine elements of cognitive, technical, and attitude skills. Learning to live together as the anthesis of various forms of competition and rivalry from life such as competition, disputes, quarrels, and wars in various sectors of life, will build a spirit of peace, togetherness, harmony, and harmony in life through collaborative efforts or work to achieve goals. The main capital in the success of students so that they have competencies that are able to realize lifelong learning (Rifai, 2016).

Religious-based universities are highly expected in the formation of students' moral characteristics. One of the religious-based universities in Indonesia is the State Islamic University. The direction of learning in higher education based on religious education is usually directed at elements of knowledge and attitude. The attitude element is intended to be able to show religious attitudes as Muslims, believers and muhsin who are tolerant, moderate and uphold human values in carrying out their duties based on Islamic morals and ethics. The element of knowledge is intended to be able to formulate procedural problem solving based on an approach to Islamic educational values; mastering the philosophical and theological foundations about the nature of monotheism in students who have prophecies and personal Muslim treatises so that they can contribute to the benefit of the people according to their expertise (De Cruz \& De Smedt, 2015).

The values contained in the vision and mission of the university are difficult to be internalized into the competence of the study program. The assumption is that the curriculum is not compatible with the higher education paradigm itself. The competency-based curriculum should have internalized the values of the university education paradigm, especially religious-based universities in which have a general study program. The values of the higher education paradigm must be transferable into the profile and competence of the study program. It is necessary to use a social reconstruction approach that considers the characteristics of the objectives and content of the curriculum that can be seen from the learning design. It requires steps in the long term and focused on science and attitude. The current curriculum development process must be progressive and requires the principles of naming difference theory, value-oriented, learner-centered, constructivist, re-conceptualist, social-reconstructive, and humanist theory so that it emphasizes interests, needs, and background of students both individually and in groups (Melesse \& Belay, 2020). The role of education in the $20^{\text {th }}$ century are more programmed in various criticisms, reflections, and actions as an effort to establish causality between education and social harmony (Carneiro \& Draxler, 2008).

The curriculum preparation with a learning approach was formulated on the objectives of education programs, competencies, learning and teaching materials, subject structure and course distribution (Sukmadinata \& Syaodih, 2012). Teaching materials are a form of material used to assist teachers in the learning process (Hamsiah et al., 2019). The teaching materials in it contain learning messages and require certain skills and management compared to conventional ones (Mulyasa, 2006). The textbook analysis was important in supporting education reform. Conducting textbook research is important in highlighting best practices in the field (Okeeffe, 2013).

Research-based teaching materials are an important tool in improving the quality of learning. The first step that should be chosen to develop research-based teaching materials is to choose the right textbook and can create access for students to the textbook. One of the efforts so that teaching materials are suitable for use, it is necessary to make learning designs through the RBL (Resource Based Learning) strategy model, which is a learning system based on learning resources used in the process of teaching and learning activities in the classroom. 
The main rule used in the selection of this textbook was the novelty and depth of the study (Yahya, 2010). The RBL strategy can be used as a learning diagnostic procedure in assessing and practicing reading notes (Westwood, 2016). The procedure can be through learning models such as authentic learning, problem solving, cooperative learning, contextual approach, the principle is student-centered learning.

The current teaching materials did not meet students' needs in learning (Arsanti, 2018). A lecturer is required to conduct an evaluation to be more effective in improving student competence and education in general (Tjabolo \& Otaya, 2019). The learning materials for university courses that have a religious education paradigm are very difficult to integrate into the vision and mission or profiles of graduates of general studies programs. The distribution of courses collected at religious education-based universities are religious courses that must be followed by all students at the religious-based university.

This study aims to investigate the educational paradigm of a religious-based university can be formulated into course learning materials as a core study material for a religious-based university and can be implemented in the lecture process in order to support the profile and competence of study program students. One of the religious-based universities in Indonesia is UIN Sunan Gunung Djati Bandung which uses a competency-based curriculum referring to the Indonesian National Qualifications Framework which focuses on developing professional competencies both technically and conceptually (sixth-level). The formulation of the form of competency work is in the competency unit of the subject, and sub-subject. One of them is in the English literature study program. The profile formulated in the English Literature study program is to become a language analyst, literary analyst and intermediate translation expert (Budi \& Muslim, 2019).

The types of religious-based university courses (Islamic universities) are Islamic Studies courses that map out seven other Islamic courses in the next semester. They implicitly have aspects of the cognitive, affective and psychomotor domains that determine each other. The Islamic Studies course as one of the university courses becomes a supporting competency course for the competence of study programs, especially general study programs (nonreligious study programs). This course must be able to support the learning outcomes of the study program so that it can contribute to the formation of the profile of the study program and in accordance with the university's vision and mission. The course should be designing in such a way to internalize the values of Islamic education through the learning process. It is necessary to make a research-based teaching material for students that is adjusted between the paradigm of university education based on Islamic education and the profile of general study programs that can be actualized by students to become student competencies in accordance with the vision of a religion-based university and the study program it supports.

Islamic Studies courses as university content courses need to be tested in order to measure student competencies (Eisenberg, 2013). In this case, the direction of learning needs to be directed at the learning information age that prioritizes attainment-net-based, personbased and resource-based. In principle, the learning strategy must consider the learning objectives, the essence of teaching materials, and the needs of students as the subject to be studied.

The effective thing to connect the three basic learning directions, researchers use cooperative learning strategies with the aim of finding student performances in processing learning material information, evaluating individual responsibilities, providing opportunities for exchanging ideas between students, training students to participate actively and communicate through problem solving so that learning outcomes can be identified based on students' logical reasoning abilities in solving problems by identifying the character of thinking patterns and how to process information. Reasoning in solving problems is an important thing 
that needs to be developed through learning, but the ability to solve problems for students is still low and is considered difficult. It was low and difficult for students to solve problems because the learning design did not create or provide opportunities to develop students' reasoning abilities. The problem-solving skills need to be developed in learning; the indicator is logical reasoning. In this case, thinking style and process student information were analyzed based on the topics of teaching material so that students are able to understand, apply and identify themselves as students of the study program. The goal of Islamic Studies competence is manifested in the profile of the study program (in this case at sixth-level). Sixth-level is the analytical competency that must be achieved by the undergraduate level (Zakir, 2015). This kind of study which is trying to reveal the internalization of research-based learning materials especially in Islamic higher institution context is still rare to do. The recent studies are commonly conducted in public institutions rather than Islamic institution. Therefore, this study is trying to find out the phenomena of how it can be implemented in Islamic higher institution context.

\section{METHOD}

This research used a qualitative method based on observations and questionnaires as an action test of product analysis of draft study materials in order to find effective teaching material products in achieving the learning goals (Creswell, 2015). Field observation data were collected based on direct observations. Study participants are students of the English Literature study program at UIN Sunan Gunung Djati Bandung in the first semester of the 2019-2020 academic year classes A, B, C and F. The action steps for testing teaching materials are carried out first by making learning concepts, including making drafts of adapted teaching materials with university study materials and study program materials, then conduct initial observations in exploring potentials and problems in the classroom, followed by designing learning models that will enable students to build a learning environment, including information processing, social, personal teaching models, and systems learning models (Bruce Joyce, 2009). The objects observed were the activities of students' thinking styles, problemsolving abilities in processing information and students' attitudes in taking the values of religious education. Students are given the task of making literary works for analytical researchers based on the internalization of religious (Islamic) values obtained from the learning process of Islamic studies into their literary models. Next, identify the needs and abilities of students by making improvements to teaching materials to suit student needs, revising drafts of book product materials, editing product drafts, re-correcting products, making product improvements, making mass products, and making research reports. The steps for implementing the feasibility of teaching materials on research-based student learning characteristics can be illustrated in the form of Figure 1 and Figure 2.

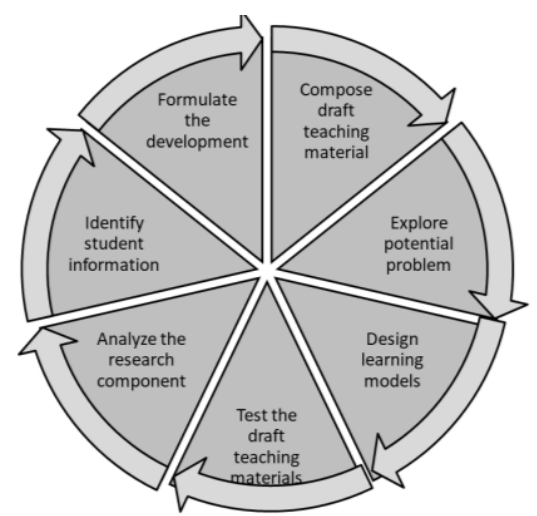

Figure 1. Feasibility Process for Research-Based Teaching Materials 


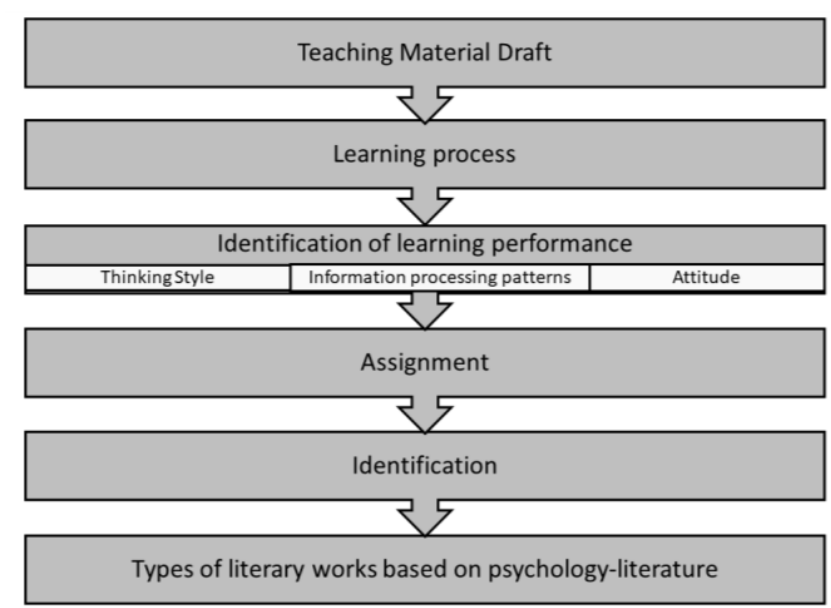

Figure 2. Process of Learning Performance Analysis and Internalization of Students' Religious

\section{RESULTS AND DISCUSSION}

Based on the results of observations during one semester, it was found that several thinking styles, problem solving abilities in processing information and student attitudes in taking Islamic education values from the implementation of teaching materials trials in Islamic Studies course lectures in Table 1.

Table 1. Students' Thinking Styles, Problem Solving Abilities in Processing Information, and Attitudes

\begin{tabular}{|c|c|c|c|c|c|}
\hline Class & $\begin{array}{c}\text { Aspects of } \\
\text { Thinking Style }\end{array}$ & $\begin{array}{c}\text { Types of } \\
\text { Thinking } \\
\text { Techniques }\end{array}$ & Processing Information & Attitudes & $\begin{array}{c}\text { Types of Literary } \\
\text { Works }\end{array}$ \\
\hline $\mathrm{A}, \mathrm{F}$ & $\begin{array}{l}\text { - } \text { Think } \\
\text { regularly } \\
\text { - Logical } \\
\text { feedback } \\
\text { - Reality } \\
\text { - Organized }\end{array}$ & $\begin{array}{l}\text { Concrete } \\
\text { Sequential }\end{array}$ & $\begin{array}{l}\text { - Step by step } \\
\text { - Based on a series of } \\
\text { memory functions } \\
\text { - Sorting topics } \\
\text { - Connect topic in memory } \\
\text { - Details }\end{array}$ & $\begin{array}{l}\text { - Tolerant } \\
\text { - Remind } \\
\text { - Objective } \\
\text { - Opened }\end{array}$ & $\begin{array}{l}\text { Extroversion } \\
\text { thinking }\end{array}$ \\
\hline B & $\begin{array}{l}\text { - Experimental } \\
\text { - Irregular } \\
\text { (skipping) } \\
\text { - Creative } \\
\text { - Find your self } \\
\text { - Random } \\
\text { Concrete }\end{array}$ & $\begin{array}{l}\text { Random } \\
\text { Concret }\end{array}$ & $\begin{array}{l}\text { - Don't collapse (random) } \\
\text { - Divergent } \\
\text { - Prepared } \\
\text { - Focus on time } \\
\text { - Requires direction }\end{array}$ & $\begin{array}{l}\text { - There is a } \\
\text { change } \\
\text { effort to } \\
\text { respect } \\
\text { each other } \\
\text { - Mutually } \\
\text { support }\end{array}$ & $\begin{array}{l}\text { extroversion } \\
\text { intuitio }\end{array}$ \\
\hline $\mathrm{C}$ & $\begin{array}{l}\text { - Emphasize } \\
\text { feelings } \\
\text { - loyal listener } \\
\text { - Calm / } \\
\text { peaceful } \\
\text { - The existence } \\
\text { of reception }\end{array}$ & $\begin{array}{l}\text { Random } \\
\text { Abstract }\end{array}$ & $\begin{array}{l}\text { - Reflective } \\
\text { - Listeners to the bitter end } \\
\text { - Have your own way } \\
\text { - Decide the conclusions } \\
\text { that are initiated } \\
\text { - Preparing myself } \\
\text { - Make presentations in } \\
\text { rotation based on } \\
\text { spontaneous agreement } \\
\text { - Focus on the core } \\
\text { material }\end{array}$ & $\begin{array}{l}\text { - Appreciate } \\
\text { time } \\
\text { - There is a } \\
\text { positive } \\
\text { invitation }\end{array}$ & $\begin{array}{l}\text { Extroversion } \\
\text { feeling }\end{array}$ \\
\hline
\end{tabular}

This research is strengthened by the opinion of students (as many as 69 students) about their self-description when the Islamic studies learning process takes place which is carried out through a random questionnaire, including thinking activities, how to process information, and their learning performance attitudes based on their own perspectives. 


\section{Students' Thinking Style}

The first thing to find out in this study is the students' thinking styles. The result of students thinking styles are listed in Table 2.

Table 2. Students' Thinking Styles

\begin{tabular}{lcl}
\hline Subjects & Number & Percent \\
\hline Think regularly & 11 & $16,40 \%$ \\
\hline $\begin{array}{l}\text { Thinking back and forth } \\
\text { Disorganized thinking } \\
\text { (jumping) }\end{array}$ & 16 & $23,90 \%$ \\
\hline $\begin{array}{l}\text { Think in an organized way } \\
\text { Thinking logic }\end{array}$ & 9 & $19,40 \%$ \\
\hline Think according to reality & 22 & $32,04 \%$ \\
\hline Experimental & 6 & $9 \%$ \\
\hline Creative thinking & 6 & $9 \%$ \\
\hline $\begin{array}{l}\text { Think by finding yourself } \\
\text { Prioritizing feelings or } \\
\text { experiences }\end{array}$ & 6 & $9 \%$ \\
\hline $\begin{array}{l}\text { Listening faithfully while } \\
\text { thinking }\end{array}$ & 32 & $11,90 \%$ \\
\hline Think calm and peaceful & 4 & $6 \%$ \\
\hline Think and accept & 24 & $35,80 \%$ \\
\hline
\end{tabular}

The majority of students' thinking styles are listening faithfully while thinking 32 $(47.80 \%)$. It was followed by thinking logic $(43.30 \%)$ and think according to reality $(32.80 \%)$. It proves that most of students do have a deep focus while they learn by doing it faithfully based on the logical thingking and reality. However, the moderate amount of their thinking style (thinking back and forth, disorganized thinking (jumping), and think regularly) also showed that the students still showing inconsistencies during their learning process. It is quite common due to their younger age of study. Overall, their thinking styles can be concluded:

1. The average patterned on three thinking styles: sequential concrete, concrete abstract, and abstract random.

2. Viewed from the cognitive aspect individually, they are able to think with a pattern of induction (inductive thinking), find concepts (concept attainment), learn scientific research (scientific inquiry), through information processing, mnemonics (assimilate information), think creatively through collaboration (synthetic), understanding knowledge in a cognitively structured manner from the results of their collaborative presentation (advance organizer).

3. In terms of general skills (soft skills), through group learning they are able to give birth to social learning through pattern in learning and group investigation, which can be seen from their ability to improve self-concept through presentations (enhancing self-concept through presentation) based on observations. learning behavior systems master the material and make planned instructions, respect each other, complement each other, and give each other opportunities.

\section{Students' Attitudes}

Students' attitudes during the learning process then becomes the second thing to see.

Based on the questionnaires the students attitudes are listed in Table 3. 
Table 3. Students' Attitudes during the Learning Process

\begin{tabular}{lcc}
\hline Subjects & Number & Percent \\
\hline Tolerant & 35 & $50,70 \%$ \\
\hline Remind & 9 & $13 \%$ \\
\hline Objective & 20 & $29 \%$ \\
\hline Open & 44 & $63,80 \%$ \\
\hline Inviting change effort to respect each other & 19 & $27,50 \%$ \\
\hline Mutual support & 14 & $20,30 \%$ \\
\hline Appreciate time & 7 & $10,10 \%$ \\
\hline Inviting to positive things & 15 & $21,70 \%$ \\
\hline
\end{tabular}

The majority of students' attitudes during the learning process are open $44(63.80 \%)$, tolerant $35(50.70 \%)$ and objective $20(29 \%)$. It showed that the students have the openminded way during their learning process. They are open to every knowledge that they get and they are also tolerant to the different kind of information they already knew. The objectivity then becomes another plus point of their attitudes to proceed the information during their learning process. On the other hand, remind and appreciate time are the lowest number of attitudes showed by students. It means that they still struggling on managing their time during their studies. It is really common since time management is the thing that can be learnt gradually during their study.

The students have social learning through an attitude of compliance, namely accepting the influence of others in the hope of getting a positive reaction from other parties, namely showing an open, tolerant, but objective attitude, inviting change effort to respect each other, Inviting to positive things, Mutual support. In addition, the attitude of internalization appears to be owned by students because they adjust to what they believe to be a value system that appears in an attitude that invites mutual respect. Finally, they have an attitude of identification with the hope of having the same attitude, this is especially evident in the attitude of inviting positive things.

\section{Students' Management of Information}

Information system (IS) refers to a strategic planning which is used to develop a taxonomy for evaluating and understanding the benefits. In addition, this taxonomy serves other functions. It may also be used as a tool to support the planning team. The team is responsible to handle and manage IS planning process. To provide a bigger picture on this aspect, the following table illustrates how IS works.

Table 4. How Students Manage their Information during Learning Process

\begin{tabular}{lcc}
\hline Subjects & Number & Percent \\
\hline Processing step by step & 11 & $16,40 \%$ \\
\hline Processing based on memory sequences & 7 & $10,40 \%$ \\
\hline Sorting by topic & 6 & $9 \%$ \\
\hline Connecting topic with their memory & 5 & $7,50 \%$ \\
\hline Processing in detail & 4 & $6 \%$ \\
\hline Processing randomly according to knowledge & 5 & $7,50 \%$ \\
\hline Distinguishing and sorting information & 1 & $1,50 \%$ \\
\hline Preparing in advance & 6 & $9 \%$ \\
\hline $\begin{array}{l}\text { Listening to the end before processing the } \\
\text { information }\end{array}$ & 4 & $6 \%$ \\
\hline $\begin{array}{l}\text { Focusing on the core material } \\
\text { Processing based on agreement and } \\
\text { presenting it }\end{array}$ & 3 & $4,50 \%$ \\
\hline
\end{tabular}


Table 4 showed the way students processing the information during their learning process. The majority of their ability to process information is in processing step by step $11(16.40 \%)$ and processing based on their memory sequence $7(10.40 \%)$. It showed that the students are quite well managed in study. They do the steps sequentially and connected the materials with their memory. However, there is the lowest number of how the students manage their information which is distinguishing and sorting information $(1,50 \%)$. It showed that the ability of students to select and sort the information still need to be improved and exposed since these are the important things to do to filter the information during their learning process.

In general, they way their manage the information they get are in several kinds:

1. Organizing learning through the division of discussion topics in detail, in the form of slabs of material, and some through reflective ideas.

2. Material exploration is dominated by random knowledge exploration.

3. Regulating the learning work environment, some focus on the division of discussion tasks, some focus on the duration of the presentation time, some focus on preparing themselves for their turn spontaneously, there is also a focus on preparing themselves to take turns in a chain according to the topic of discussion.

Based on the acquisition of thinking styles, information processing styles and the internalization of their attitudes in the learning process, it can be seen that the internalization of their Islamic educational values in the type of Islamic literature on literary characters that are extroversion thinking, extroversion intuition, and extroversion feeling. This can be seen from the collection of assignments to make literary works released according to their wishes in the form of novels. Figure 1a and 1b shows the students' activities in the lecture process.

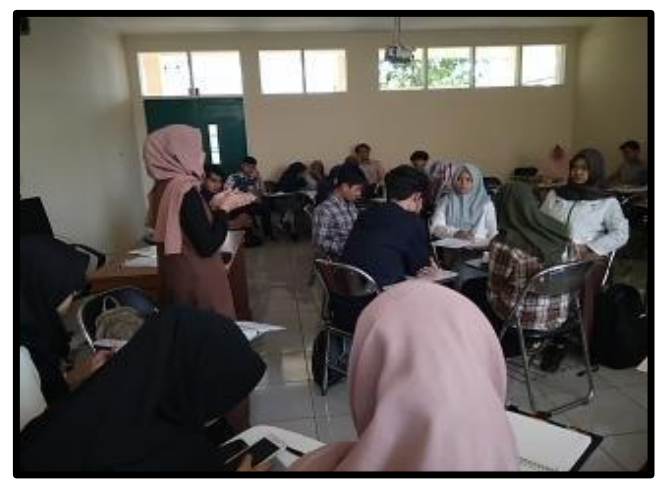

Figure 1a. Student Activities in the Lecture Process

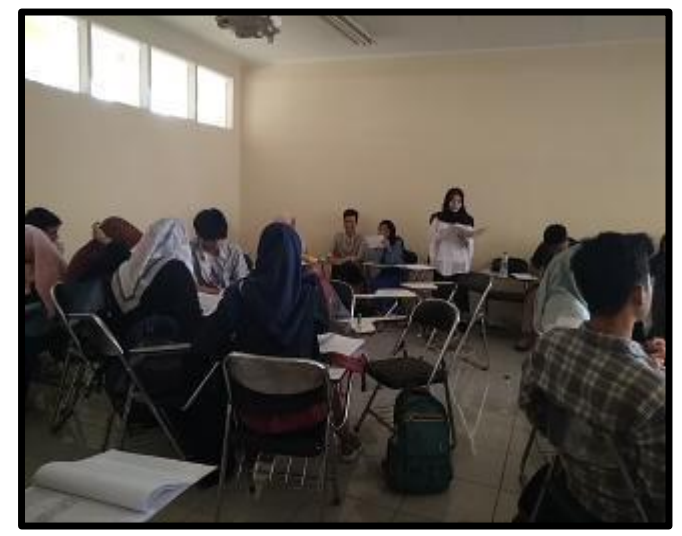

Figure 1b. Student Activities in the Lecture Process 


\section{Development}

The draft of learning materials for Islamic Studies courses can be used as a map to the construct of student knowledge in the aspect of internalizing the values of Islamic education in universities with a religious paradigm. The motivation is that lecturers must be able to innovate to build important environments in the knowledge construct by learning how to learn well for students. The building environment can be chosen in the form of teaching models that can build their knowledge such as the information-processing teaching model, the social teaching model (the social family), the personal teaching model (the personal family), and the behavioral system learning model (the social family), and behavioral systems family (Bruce Joyce, 2009).

Drafts of teaching materials that are juxtaposed with appropriate learning models must be able to stimulate students' thinking so that competencies can be found in how to process information either by induction (inductive thinking), finding concepts (concept attainment), studying scientific research (scientific inquiry), assimilating information (mnemonics), creative thinking through collaboration (synthetic), cognitive structure in understanding lecture presentations (advance organizer), as well as social teaching models that shape the competence of student learning partners with their friends (pattern in learning) and students are able to conduct group investigations (group investigation).

The implementation of research-based teaching materials that are tailored to the needs and abilities of students personally has been proven to be able to form a reciprocal relationship between lecturers and students, including: (1) The task of the lecturer directs, assists and clarifies learning objectives to students as well as providing the necessary assistance so that students are able to solve their own problems so that they can receive the benefits of being able to improve their self-concept through presentations (enhancing self-concept through presentation) such as the ability to argue, communicate, collaborate, and internalize the material in ways of thinking and behaving. (2) The benefit for lecturers is that they can identify students' information needs to be poured into teaching materials to make them more comprehensive. Meanwhile, from the attitude system of students in forming learning abilities, they can master the material and be able to make planned instructions. So that students are able to learn based on the stimulation provided in the form of teaching materials to be developed through training and self-training to develop materials and internalize selfcompetence. And for lecturers, it can help increase the insight of pedagogic knowledge that has not been reached on the student side.

The content of the material can be designed in the form of knowledge that can be affectionately connected between Islamic values as the university's vision and the competence of study programs, in this case Islamic-based literature. The material provided is essentially more directed to material related to religious phenomena and Islamic principles that can form attitudes to life that can be internalized in the profile of graduates of the study program. The identification of current student information needs show in Table 5. 
Table 5. Identification of Current Student Information Needs

\begin{tabular}{|c|c|c|}
\hline No. & Information Needs & Action \\
\hline 1 & $\begin{array}{l}\text { Islamic Studies in Europe, America and } \\
\text { Australia }\end{array}$ & Associate with history and present \\
\hline 2 & $\begin{array}{l}\text { Religious phenomena and developments } \\
\text { on human life and life }\end{array}$ & $\begin{array}{l}\text { Give an explanation of the nature (fitrab) of } \\
\text { religious human impact on doctrine, social } \\
\text { interaction, culture, anthropology }\end{array}$ \\
\hline 3 & $\begin{array}{l}\text { Islam as a religion in accordance with } \\
\text { the nature (fitrab) of human }\end{array}$ & $\begin{array}{l}\text { Add about Islam a religion that is fitrah, a religion } \\
\text { that is the universality of Islam, a religion that } \\
\text { teaches monotheism, a religion that is empirical, } \\
\text { rational and science, methods and approaches to } \\
\text { Islamic studies }\end{array}$ \\
\hline 4 & The Urgency of Islam for Humans & $\begin{array}{l}\text { Give an explanation of the Islamic concept of } \\
\text { human events, about life, tasks, roles and } \\
\text { positions of human life in the world. Also talk } \\
\text { about reason and revelation }\end{array}$ \\
\hline 5 & Plurality of Islamic Religion & $\begin{array}{l}\text { Add an explanation of the development of Islamic } \\
\text { study thinking about faith, Islam, and ihsan, the } \\
\text { source of teachings and ijtihad their implications } \\
\text { for sects, schools, congregations, and their } \\
\text { development of science }\end{array}$ \\
\hline 6 & English literature and literature in Islam & $\begin{array}{l}\text { Add information about literature in the Islamic } \\
\text { world and literary rules in Islam }\end{array}$ \\
\hline
\end{tabular}

Research shows that the draft study material implemented through the learning process in the classroom results in student performance which results in the internalization of Islamic educational values, in the form of thinking styles, ways of processing various information and forming attitudes and knowledge, extroverted works (influenced by material and other people). Thus, the feasibility of research-based teaching materials is important to harmonize the university education paradigm with the competencies of graduate study programs needed by students by testing drafts of course study materials in the learning process by using innovative learning model strategies and then connecting them with thinking styles and patterns of processing natural information. students so that they can know the characteristics of competencies that need to be explored and information needs that need to be developed in course teaching materials.

Research shows that the draft study material implemented through the learning process in the classroom produces student performance that results in the internalization of Islamic educational values, in the form of thinking styles, ways of processing various information and forming attitudes and knowledge, then when connected to the competence of study programs in the form of producing extroverted works (influenced by material, and other people). Thus, the feasibility of research-based teaching materials is important to harmonize the university education paradigm with the competencies of graduates of study programs needed by students, namely by testing drafts of course study materials in the learning process by using innovative learning model strategies and then connecting them with thinking styles and patterns of processing information. Their natural nature so that they can know the characteristics of competencies that need to be explored as well as information needs that need to be developed in course teaching materials.

The discussion draft of teaching materials is packaged by chapter which is arranged based on the nature, scope and objectives of the study which is externalized to the 
performance and competence of students that are tailored to their needs and directed at the profile and characteristics of learning outcomes for study programs and universities. The contents of the study include: learning concept maps, competency standards and introduction to subject dissemination; background in Islamic Studies as a subject discipline; History and development of Islamic studies; Religious Studies and the phenomenon of religious people; Islam as Religion; Substance of Islamic Religious Teachings; The Urgency of Islam for Humans; Islamic concepts of man, reason and revelation, Philosophy, Science, Culture, Language, Arts and Literature; The Development of Islamic Thought; Islamic Concepts on Philosophy, Science and Religion; Ijtihad as the Dynamics of Culture and Civilization; Islam and the Contemporary World; Areas of Islamic Studies, Literature in Islam and Islamic Literature.

Thorndike's connectionism theory or also known as association theory is the main theory in this research. This theory states that the association between sensory impressions and impulses with action as a bond or connection is called a connection, how ideas become interrelated, the emphasis is on the functional of behavior. The most basic form of the learning process in this theory is trial and error learning or also called selecting and connecting. This theory says that learning is incremental, not direct to insightful meaning in other words learning is done through small systematic steps in the form of direct selection and attribution in learning, not direct reasoning (Schulz, 1976; Olson, 2008). The principle is to start with the law of readiness, the law of exercise, then the law of effect (Amsari \& Mudjiran, 2018). Therefore, it is possible for learning activities to adapt or respond according to the situation (law of assimilation or law of analogy).

This theory involves stimuli in influencing individuals to respond. The connection between stimulus and response is said to be strong if there is a probability. Stimulus is used for a change from the external environment so that it becomes a sign in activating the organism to act, while the response is any behavior that arises because of the stimulus. In this case, the task of the lecturer is to provide stimulation so that the learning process occurs and confirms the correct response such as self-esteem, expectations, praise and attention to maintain behavior, as well as teaching materials as side reinforcement (Langgulung, 2000).

Regarding the indicators of students' thinking styles, this study uses the Quantum Learning theory from Bobi De Porter and Mike Hernacki which suggests four types of thinking styles, including concrete sequential thinking style (SK), concrete random thinking style (AK), abstract random thinking style (AA), and abstract sequential thinking style (SA) (Hernacki, 2015). While the information processing process indicators use information processing theory from Robert Mills Fagne which says that individuals can facilitate the process of obtaining information starting from encoding (assuming information), storage (information storage), then retrieval (revealing stored information) (Ismail, 2015). In terms of educational psychology, responses and information processing processes will be affected by attitudes. The theory for measuring attitude indicators in this study uses the attitude organization theory of Kelman (1958) which states that there are three social processes in the process of changing human attitudes, including compliance, identification, and internalization (Kelman, 2005). Adding Pierre Felix's opinion which explains that there are three theories of attitude, including (1) learning and reinforcement theory (learning information through values and feelings based on facts), its form can be in the form of an imitation process (imitating other people's attitudes), (2) incentive theory (responding with using several kinds of thoughts can be positive or negative by considering the value of the advantages or disadvantages, (3) cognitive consistency theory, namely connecting meaning to a stance (Savitra, 2017).

The three aspects of the theory above are connected with the assignment to make literary works. To analyze his literary works, the researcher uses the psychological theory of 
C.G. Jung's typological construction (1875-1961). In relation to literary works, there are six personal types that are influenced by psychological factors in making literary works, including the personality types Introversion-thinking, extraversion-thinking, introversion-feeling, extroversion-feeling, introversion-sensing, and extroversion-intuitio (Periantalo \& Azwar, 2017). Factors that influence the psychological type which is dominated by personal factors can be because of curiosity motives, competence motives, love motives, self-motives and the desire to find identity, value motives, self-fulfillment motives, attitudes and emotions, and so on.

\section{CONCLUSION}

Designing research-based textbooks can be tested first through the design of teaching materials that are connected to learning outcomes or university profiles and expected study programs, then implemented in the learning process by creating stimulation to students' natural competencies with the principle of Student-Centered Learning. The competency stimulation media can be in the form of individual and social-based learning designs and models such as processing information (the information-processing family), social teaching models (the social family), personal teaching models (the personal family), and behavioral systems learning models (the behavioral) systems family collected by Bruce Joyce. Teaching materials that are connected to the student learning process are then identified with thinking styles and how to process students' natural information, then applying the assignment of study program competencies (in this case the form of an assignment to make literary works) will easily find up-to-date information needs. The internalization of the values of Islamic education as the core competence of a religion-based university towards the competence of graduates (study program profiles) can be measured, namely as an Islamic study program analyst (literary graduate/S1) (ulul albab) through their works. It is important to conduct trials of researchbased teaching materials to match the profile of graduates from the study program and the paradigm of university education, including: (1) lecturers must know and understand the vision and mission as well as the profile of universities and study programs, (2) lecturers must be sensitive to the development of contemporary science needed by students, (3) lecturers must have knowledge of psychology and pedagogics in stimulating students so that students' latent competencies can be stimulated, (4) lecturers must make connections between teaching materials, the learning process with the vision and mission of the university and study programs regarding competencies. It is hoped that, (5) lecturers must be able to stimulate the initial competencies of students they already have through problem-based learning, (6) build student creativity through assessments that are adapted to the educational paradigm and profiles of university graduates and study programs, (7) lecturers must be able to explore religious potential to connect with computer student study programs, (8) and more importantly, lecturers are able to enjoy their profession as lecturers in advancing their students.

\section{ACKKNOWLEDEMENT}

This research received funding from the DIPA-BOPTAN of the Ministry of Religion and UIN Sunan Gunung Djati Bandung through a grant writing a book based on research based on litapdimas research in 2019 with Registration number 194080000015636 Cluster Publishing Textbooks/Texts/Daras/Reference Based Research (PT), SK Rector of UIN SGD Bandung Number: 193 /Un.05/V.2/Kp.02.3/04/2019, the researcher should thank the Minister of Religion of the Republic of Indonesia and the Chancellor of UIN Sunan Gunung Djati Bandung who have helped fund the publication of this textbook/daras. Thank you also to LP2M and LPM UIN Sunan Gunung Djati Bandung who have made the publication of this book smooth. 


\section{BIBLIOGRAPHY}

Amsari, D., \& Mudjiran. (2018). Implikasi Teori Belajar E. Thorndike (Behavioristik) dalam Pembelajaran Matematika, Jurnal Basicedu, 2(2), 52-60. https://doi.org/10.31004/ basicedu.v2i2.168.

Arsanti, M. (2018). Pengembangan Bahan Ajar Mata Kuliah Penulisan Kreatif Bermuatan Nilai-Nilai Pendidikan Karakter Religius Bagi Mahasiswa Prodi Pbsi, Fkip, Unissula. Kredo: Jurnal Ilmiah Bahasa dan Sastra, 1(2), 71-90. https://doi.org/10.24176/ kredo.v1i2.2107

Budi, K. S., \& Muslim, S. (2019). The Development of Indonesian National Qualifications Framework (INQF)-Based Electrical and Electronic Subject at Vocational High School Kal-1 Surabaya. Humanities \& Social Sciences Reviews, 7(3), 315-322.

Carneiro, R., \& Draxler, A. (2008). Education for the 21st Century: Lessons and challenges. European Journal of Education, 43(2), 149-160. https://doi.org/10.1111/j.14653435.2008.00348.x

De Cruz, H., \& De Smedt, J. (2015). A natural History of Natural Theology: The Cognitive Science of Theology and Philosophy of Religion. MIT Press.

Eisenberg, J., Lee, H. J., Brück, F., Brenner, B., Claes, M. T., Mironski, J., \& Bell, R. (2013). Can Business Schools Make Students Culturally Competent? Effects of Cross-Cultural Management Courses on Cultural Intelligence. Academy of Management Learning \& Education, 12(4), 603-621. https://doi.org/10.5465/amle.2012.0022

Hamsiah, A., Muhammadiyah, M., \& Asdar. (2019). Pengembangan Bahan Ajar Berbasis Nilai Budaya Sebagai Strategi Pelestarian Budaya. Jurnal Ecosystem, 19(1), 10-18. Retrieved https://ecosystem.unibos.id/index.php/eco/article/view/140

Hergenhahn, B. R. \& Olson, M. H. (2008). Theories of Learning, edisi ke 7, Jakarta: Kencana Prenada Media Group.

Joyce, B., Weil, M. \& Calhoun, E. (2009). Models of Teaching, Yogyakarta.

Kelman, H. C. (2005). Continuity and Change: My Life as a Social Psychologist. The Social Psychology of Group Identity and Social Conflict: Theory, Application, and Practice, 233-275. https://doi.org/10.1037/10683-013

Melesse, S., \& Belay, S. (2020). Curriculum Conceptualization, Development, and Implementation in the Ethiopian Education System: Manifestations of Progressive Curriculum Orientations. Journal of Education. https://doi.org/10.1177/ 0022057420966760

Okeeffe, L. (2013). A Framework for Textbook Analysis. International Review of Contemporary Learning Research, 2(1), 1-13. https://doi.org/10.12785/irclr/020101

Ouharzoune, Y. (2015). Live Together!. In Soins 60(799). https://doi.org/10.1016/ j.soin. 2015.08 .020

Periantalo, J., \& Azwar, S. (2017). Pengembangan Skala Kepribadian Siswa SMA dari Tipologi Kepribadian Jung dan Myers-Briggs. Jurnal Sains Sosio Humaniora, 1(2), 191-207. https://doi.org/10.22437/jssh.v1i2.4301

Rifai, M. (2016). Kurikulum Berbasis Kompetensi (Konsep Dasar dan Implementasi). Premiere Educandum: Jurnal Pendidikan Dasar dan Pembelajaran, 2(01), 38-51. https://doi.org/10.25273/pe.v2i01.46

Sugiono, (2017). Metode Penelitian Pendidikan Pendekatan Kuantitatif, Kualitatif dan $\mathrm{R}$ \& $D$, Bandung: Alfabet.

Sukmadinata, N. S \& Syaodih, E. (2012). Kurikulum Pembelajaran Kompetensi. Bandung: PT Refika Aditama.

Tjabolo, S. A., \& Otaya, L. G. (2019). The Evaluation of Islamic Education Teachers' Performance. Jurnal Pendidikan Islam, 5(1), 25-38. https://doi.org/10.15575/jpi.v5i1.3627 
Unesco, (2014). Learning to Live Together, Paris: The United Nations Educational, Scientific and Cultural Organization 7.

Westwood, P. (2016). Teaching and Learning Difficulties, 2d edition. Camberwell, Acer Press.

Yahya, I. (2010). Manajemen Empat Langkah dalam Pengembangan Bahan Ajar Berbasis Riset: Sebuah Pengalaman dari Perkuliahan Akustik di Pelatihan Penulisan Buku Ajar Berbasis Riset, yang Diselenggarakan Oleb LPPM UNS, 1-6. Retrieved from http://iwany.staff.uns.ac.id / files/2010 /10/research-enhanced-teaching_okt2010.pdf

Zakir, M. (2015). Description of Logical Reasoning in Solving Mathematics Problemss Based on Students' Thinking Style of Students at SMPN 2 Pinrang. Jurnal Daya Matematis, 3(2), 152. https://doi.org/10.26858/jds.v3i2.3229 